\title{
Problems of Privatisation and Regulation in Transition Economies
}

\author{
Asst. Prof. Dr. Yeşim Reel (Marmara University, Turkey)
}

\begin{abstract}
In spite of difficulties, most transition economies in the Former Soviet Union (FSU) and Eastern Europe now have private sectors whose relative size is comparable to the private sectors in Western European countries. The transition countries have had very different objectives, but most started privatisation more or less with the same policy, based on the experience of the United Kingdom, although this was soon to change. While most of the Eastern European countries were fast to adopt modern standards and regulations, some FSU countries have lagged behind. Along with a wide range of gains for producers and consumers, there have been drawbacks, such as social polarisation and forms of capture (of business, of the state). Unlike most analysis of transition, which considers major components, this paper looks at the microeconomics of transition, since this involves the creation of markets through the process of privatisation. In general, transition economies have to develop new institutions and polices to support the privatisation and restructuring. In addition to these, they require regulation, which has been under-developed and causes other, different problems, related to the development of new models. Therefore, the need for a new, third phase of transformation is highlighted. New initiatives on labour, capital and regulation issues become vital now in transition economies.
\end{abstract}

\section{Introduction}

The transition from state socialism to capitalism or market socialism has been a profound, indeed revolutionary, shift in the socio-economic system of countries with about a quarter of the world's population (Ellman, 2012).

Several critical issues might be related to the successes and shortcomings in transition economies including privatisation, enterprise governance and restructuring, markets and trade, legal systems, finance and corruption. Without even basic market arrangements and accompanying legal system, the process of privatisation is particularly complex and difficult involving a variety of issues that are quite different to those encountered in market economies. Moreover, privatisation is fundamental to transition, since it is, in a sense, just the beginning; after ownership arrangements are changed, it is necessary to undergo restructuring (Gregory \& Stuart, 2001).

The transition countries have had very different objectives. In Central Europe the goal was to 'return to Europe'. This meant developing a democratic political system and a capitalist economy. Countries like Poland and Hungary have been successful in achieving these goals. Politically they have had changes of power among different political parties as a result of elections. Economically, they are now capitalist economies of the European type, that is, with considerable welfare expenditures and a substantial state role in the economy. In the countries of Former Soviet Union (FSU), on the other hand, the goals were to end the rule of the Former allUnion Communist party and replace it by rule by local elites, enrich the local elites by looting the national economy, and create an economic system with substantial market elements (especially imported consumer goods). These goals have all been achieved.

In to Poland and Hungary, Slovenia, Estonia, Latvia, Lithuania, the Czech Republic, Slovakia are all democratic capitalist economies and members of the European Union (EU) (Ellman, 2012). It might be suggested that, for these countries, being successful in the transition process has largely been the result of EU accession efforts. The adoption process requires special conditions to be met by potential members, and these countries have tried to make their best efforts to this end. Of course, all transition countries did not have the same characteristics and destinations, and some have made more progress in transition than others, while even the countries that have made the best efforts need to continue to make improvements, for a number of reasons.

The outline of this paper is as follows. The next section presents the main characteristics of transition economies. Then, the third section analyses privatisation and regulation problems in transition economies. This section is divided into two subsections. The first covers privatisation experiences in transition economies, and the second analyses privatisation and regulation problems. The paper ends with some concluding remarks.

\section{The Main Characteristics of Transition Economies}

In the planned socialist economies, decision-making powers were substantially concentrated in the government, which conducted economic management by directing and encouraging other economic units to implement plans. State ownership was dominant, with enterprises deprived of powers to make business management decisions. Free transactions and free competition had usually been eliminated. Capital markets had been similarly eliminated, and enterprise management linked to state finance. Monetary systems were merely complementary to state finance. 
In order to build market institutions and organizations, human resources must be developed to make up such institutions and act within the institutions for market organization purposes. People who have been used to a planned socialist economy for a long time have no experience, knowledge or know-how of a market economy. In the transition to a market economy, therefore, these people must jump into an unknown world. The government of an economy in transition needs to create market economy institutions and organizations through efforts to develop people as market economy players or actors (Nishimura, 2001).

In addition to the labour (human resources) dimension of the transition process, there are at least three basic challenges that confront governments in pursuing a transition to a market economies. The first concerns market economy policy. This is something that governments in economies in transition have generally tackled and will have to continue to do so. The second is that of economic independence. Countries that have won political independence need also to secure their economic independence. The third is economic development, because most economies in transition are low- or lower-middle-income countries. Economic development is important particularly for the governments of Central and East European countries pursuing EU accession. It is suggested that the economic policy experiences of Russia and other FSU Republics together with Eastern European countries are the most important of the challenges facing economies in transition (Nishimura, 2001).

According to Donnorummo (2006), three of the main factors that affect the relative success of a transition process are the impact of historical background and the conditions confronted by each country at the start of the transition, government reform policies undertaken during the transition, and the presence or absence of military conflicts. The historical background and conditions refer to variables such as cultural traits and values, geography, relative levels of wealth and economic structures at the start of the transition, when these variables have a strong impact. Clearly, these factors vary considerably across countries (Koyame-Marsh, 2011).

There is widespread recognition that creating competitive markets, and the infrastructure that underpins them, is an essential part of the transition process.

The potential for developing competitive markets in transition economies has been inhibited by the inadequacy of both the institutional and physical infrastructure inherited from the socialist era. There were virtually no market-oriented institutions, including legal and regulatory frameworks to enforce contracts, protect private property, and preserve a level playing field for competition and market entry. Moreover, physical infrastructure, such as transport and telecommunications, had been designed to meet the needs of a highly vertically integrated production and distribution system. Under central planning, there were very few small-to medium-sized firms, little horizontal communication between enterprises, and relatively limited provision of information to buyers and suppliers (Aghion \& Schankerman, 1999).

The transition economies continue to be characterised by the presence of major capital and product market imperfections, as well as weak regulatory and institutional regimes. These features have implied more severe, underlying problems with both incumbent monopolists and incumbent managers. For these reasons, changes in ownership without adequate attention to market structure can result in longer-term negative effects (Commander et al., 1999).

\section{Privatisation and Regulation Problems in Transition Economies}

\subsection{Privatisation Experience in Transition Economies}

Privatisation has been a particularly important phenomenon in the transition process in Central and Eastern Europe from planning to execution and functioning of a market system. This is because communist regimes had placed almost all the productive assets of the economy into state hands, partly for ideological reasons and partly to facilitate the planning process. As a result, countries like Czechoslovakia and the Soviet Union contained virtually no private sector at all - typically in excess of $90 \%$ of assets were state owned - and even in countries with slightly larger private sectors, like Poland or Hungary, private ownership was concentrated in agricultural and handicraft activities; industrial firms were all in state hands (Estrin, 2007).

Since late 1989, when communism collapsed and the Soviet Union withdrew both militarily and politically from Central and Eastern Europe, most countries in that region have gone through a considerable restructuring of their economies, including major privatization. These countries often adopted contrasting strategies, however. They not only had domestically planned economies, but also partook in economic planning at a regional level (Bjonrskov \& Potrafke, 2011).

Privatisation means the transfer of enterprises from the public to the private sector. The transfer itself involves revision to a specific law and can be implemented if the government is willing to make such change and gets social consensus to enact such. However, the transfer is only the first step of privatisation, because the transfer itself is separated from the problem of whether a new owner of a privatized enterprise can manage the enterprise as a private-sector owner. From the economic viewpoint, the essential problem with privatisation rests on this point. In this respect, the government must develop a business environment that encourage enterprise owners to manage their enterprises reasonably, establish corporate and other laws requiring and providing for reasonable 
activities on the part of privatized enterprises, and train enterprise owners as market economy actors. These are key challenges for privatisation (Nishimura, 2001).

Privatisation is a redistribution of equity rights from the state to individuals. The fundamental objective is to change the way decisions are made, so that the allocation of resources will be directed by the forces of supply and demand and profit maximization. These forces are themselves only beginning to emerge. Most microeconomic analyses of privatized enterprises in transition economies, especially in the Russian case, conclude that restructuring has not occurred. First, to the extent that state funds still find their way into enterprises, especially sectors such as heavy industry and defence, hard budget constraints have not replaced soft budget constraints. Second, although formal ownership arrangements have changed, it is not clear that the rise of barter in the late 1990s is a serious challenge to the development of a market economy in Russia. Third, in the absence of a flexible and meaningful price system, information signals in the institutional setting have limited use (Gregory \& Stuart, 2001).

The most impressive feature of privatisation in the transition economies has been the speed and scale at which it occurred. The reforming governments of the late 1980s and early 1990s managed successfully to transfer the greater part of the huge state-owned sector into private hands in a time period of hardly more than a decade and to do so they had to use innovative privatisation methods. However, this led them to introduce private ownership into situations where other crucial aspects of the business environment were not yet sufficiently developed to support the private economy. We find that privatisation appears to have provided governments with much needed revenues. However, at the enterprise level, the results on performance are patchier, although, on balance, the effects of privatisation have probably been positive, especially when the new owners were foreigners.

The most serious problem for privatization as a policy has been in situations where it has been used while the legal and institutional environment is weak (Estrin, 2007). In this situation, different institutional arrangements provide different incentives for governmental and mass privatisation institutions as they perform their role as transitional owners and final sellers in the privatisation process. The institutional framework critically affects the quality and the speed of every large privatisation program in transition economies (Simonet et al., 2004).

While most of the Eastern European countries were fast to adopt to modern standards and regulations, some FSU countries lagged behind. At the same time that Hungarian, Polish and Latvian businessmen were learning how to compete in the market, playing by the rules, Russian and Ukrainian big businessman rarely lobbied for good laws and regularly settled disputes outside of court and bribed regulators, police and political authorities to protect their property. A reformer should be afraid not of populism but of the capture of politics by the new elites (Sonin, 2013).

Most countries of the FSU have not obtained much economic freedom, getting heavy and corrupt administrative regulation instead, in the form of lengthy, complicated and non-transparent entry regulation and a variety of regulations on existing business. These regulations benefit corrupt bureaucrats (who collect bribes in exchange for getting around rules) and incumbent monopolies (as entry barriers protect them from potential competition both in the product and labour markets) (Sonin, 2013).

The introduction of (legal) private trade, private production and private ownership of the means of production has brought many benefits to the populations of the transition countries. For entrepreneurs, it has brought the possibility of developing and marketing new products and processes. For workers, it has brought a choice of employers. For consumers, it has brought a much wider assortment of goods and services. However, the efficiency-raising effects which economists expected from the privatisation of state-owned enterprises often did not materialise, or not, at any rate, in the short term. In some countries, privatisation led to a dramatic polarisation of society, with a small, very rich minority of politically well-connected people on hand, and a large impoverished part of the population, on the other. This is one of the explanations for the widespread nostalgia for the old system (Ellman, 2012).

From the beginning, the transferring of property rights from the state to the private sector was seen as an essential part of the transition process. The privatisation process turned out to be a very complex process. Citizens had little non-labour wealth and the institutions needed to support good corporate governance in a market system did not exist (Miller, 2013).

The process of large-scale privatization in FSU economies was a historically unprecedented experience for which no ready recipes existed. Most economies in transition started privatisation more or less with the same policy, based largely on the experience of the United Kingdom. This involved a reassertion of the state's property rights over enterprises (called, in general, 'commercialisation') and a centralized policy of sales after a process of valuation of the enterprises picked out by government for privatisation. This policy was quickly abandoned in all countries.

Later in the transition process, one would might have thought that all countries would converge to a policy of mass privatisation by giveaway, through vouchers. This has not been the case either. Each economy in transition developed its own privatisation policy, with different combinations of direct sales and managerial buyout, as well as vouchers. Hungary, for example, has consistently avoided mass privatisation. The actual practice of 
privatisation differs even more as some policies that appeared politically feasible in some countries did not in others where political constraints forced policy changes (Roland, 2000).

In spite of the difficulties, most FSU and Eastern Europe transition economies now have private sectors whose relative size is comparable to the private sectors in Western European countries. At this juncture in many countries, the large-scale privatisation process has largely been completed. The results, however, are mixed. Governance structures have not developed as quickly as privatisation itself.

Governance structures thus still need to be greatly strengthened before the full potential benefits of privatisation can be realised (Miller, 2013).

The private sector has, nevertheless, become an important part of the economy in most transition countries. In 13 of 28 countries in the European Bank for Restruction and Development (EBRD) studies, the private sector represented at least 70 per cent or more of GDP by 2010. In several other countries, the private sector share was between 60 percent and 70 per cent (Bosnia/Herzegovina, Moldova, Montenegro, Russia, Serbia and Ukraine). In a few countries the private sector share was much lower (Belarus [30 per cent], Tajikistan [55 per cent], Turkmenistan [25 per cent] and Uzbekistan [45 percent]). Despite these differences, the percentage share of the private sector in almost all countries has been remarkably stable over the past few years - an indication that the big push towards privatisation is largely over, even in countries where the share of the private sector is still low (Miller, 2013).

\subsection{Privatisation and Regulation Problems in Transition Economies}

In the early 1990s, privatisation was widely considered one of the keynotes of the entire transition process. The policy arguments were based on the successful experience in developed economies, as well as on evidence from developed and middle-income countries, which suggested that privatisation improves enterprise efficiency. However, it was widely recognised that privatisation on its own might not be sufficient, and that systemic changes and policy reforms were a prerequisite for successful transition (Estrin et al., 2009).

The cornerstone or key building block of capitalism (and democracy as well) is private property. Privatisation is absolutely necessary, but not sufficient, for a successful transition. Some of the errors of the early transition period were the result of a failure to fully comprehend the limitations of both the market and privatisation. There was often an over emphasis on what private ownership (or more generally, the market) by itself could accomplish. It was wrongly assumed that if a country opened its economy and privatized, all the malfunctions of the flawed communist ancient regime would disappear and matters would be set right. One can hold that this was an extremely naive expectation without being in the least bit opposed to an open economy or private property (Donnorummo, 2006).

While there was the need to privatise, it need not have been done all at once, nor was there any model that dictated how much should be privatised, even though most believe a large majority of the economy should be privatised by the end of the transition road. There was no blue print that stipulates that everything, including public transportation and the production and distribution of raw materials and energy must be privately owned. However, most transition countries have tried to apply the models of developed countries.

There is also so single specific model of capitalism (the same is true about democracy). The basics components of capitalism must exist and be dominant, but the precise shapes that these basic elements assume should be determined by the prevalent cultural values, relative strength of civil society, existing economic structures, level of economic development and security needs of each individual state/society (Donnorummo, 2006).

Furthermore, as Banerjee and Munger (2002) assert, privatisation is a means to an end rather than an end in itself. The decision to privatise is captured in three related, but distinct, dependent variables: (1) timing, (2) pace, and (3) intensity. Although political benefits may explain the timing, pace, and intensity of privatisation, in fact, the effects are very different in each case.

An important development in the FSU was the demonstration that, when the institutions necessary for an efficient market economy are lacking, just destroying the institutions of the old system and hoping that marketfriendly institutions will emerge spontaneously can have serious adverse consequences. The absence of adequate market institutions not only leads to rent-seeking behaviour by individuals and firms, but can also lead to the creation of new institutions that are incompatible with a market economy (Ellman, 2012).

Additionally, because of the restructuring was largely left to market forces, the emphasis was almost exclusively put on deregulation. This led to insufficient attention being paid to creating supportive regulations and the institutional capacity required to overcome market failures and to ensure that restructuring decisions approximate to socially desirable ones (Commander et al., 1999).

On the rebound from the experience of a totalitarian state, transition leaders went to the opposite extreme of wanting to restrict state activity to the minimum and destroy state institutions in order to allow the free play of market forces. 
In particular, the role of the state in the establishment, monitoring and regulation of institutions was neglected, in the naive belief that institutions would establish, develop and regulate themselves automatically. For example, it was asserted that a 'market springs up as soon as central planned bureaucrats vacate the field.' Markets are self-regulating mechanisms in the sense of adjusting prices to demand, supply to prices and actual to desired capacity; but they are not generated automatically nor are they self-disciplined. They are socially artefacts that rely on state authority for their validation and regulation, and often for their very existence (Nuti, 2013).

An important question raised is the size and relative strength of the state in transition economies. When the state uses regulatory institutions, this question becomes more important. Of course, the extension of the state's powers had to be severely curtailed from that which had existed in the command economy. A weak and ineffective state, as well as a state with an over powering presence or, put another way, one with either too little or too much control over the economy are both negative factors (Donnorummo, 2006).

Transformation in Central Europe and, to a much lesser degree, since 1999 also in Eastern Europe has been by and large a success story. The classical agenda of stabilisation, liberalisation and privatisation has been accomplished. None of the transforming economies are now struggling with hyper, high or even moderate inflation. None of these countries have a closed economy. The Central Europeans have joined not only the WTO (a task yet to be mastered by Russia, Ukraine and most of the New Independent States), but several of them have joined NATO, the OECD and even the EU. The latter required capital account liberalisation and reasonable exchange rate stability. Finally, as noted, privatisation has progressed considerably. Such 'strategic' sectors as energy generation and banking have also been privatised, often to foreign owners. Meanwhile the definition of the role of the public sector has remained partial and relative indeed. When it comes to a positive vision, a feasible project other than just allowing the erosion or transformation of public firms, then concepts and policies remain vague. The dangers of over-regulation and under-regulation, resulting from poor formulation of the aims, scope and means of public policy, are very real indeed.

The social resistance to privatisation, the inability to come up with a major overhaul of the welfare system and other areas requiring broad social consensus, such as the environment, defence and transport, are indicative of a need for a new, third phase of transformation. In this phase the tasks of Eastern and Central Europeans and of EU incumbents largely overlap. However, and contrary to previous stages, this time there is no 'European model' to be emulated; what is required is yet to be elaborated and tested. Moreover, the EU as an organisation is unlikely to contribute in an immediate route to overcoming these challenges. With the ongoing preoccupation with redistribution, neither political attention nor funding is likely to be focused on those areas of public sector reform where it would most be needed (Csaba, 2005).

The transition has also emphasized that what was required was not just a state that played an important role in the economy but one that acted in the interests of society as a whole - or, at any rate, of a large part of it. A major danger in some of the transition countries, in particular in the FSU, was that of state capture by elites that used the transition for their own pecuniary interests. Russia experienced, first, state capture by business interests, followed by business capture by the state, neither of which were conducive to the development of a modern market economy - the ostensible goal of the transition process. Bulgaria too is a case of very persistent state capture (Ellman, 2012). These capture cases are important in the light also of the regulatory capture problem: states with these capture problems might also follow the interests of business, instead of society, making it highly likely that regulation is captured by business interests.

For countries in transition the government is less and less an economic actor but a crucial rule maker. After the transition management role, the government must play another essential role: the guard and the guarantor of the free-market economic system. In order to maintain the viability of the free-market economy system, its borders should be safely defended by:

- 'Anti-trust' regulations (antimonopoly)

- Laws for property protection and limitation of nationalisation processes

- Fair competition legislation

- Laws for consumers protection (Scarlat \& Scarlat, 2007).

State regulations can produce both 'goods' and 'bads'. Regulation can both promote economic and social welfare and lead to significant economic and social costs. It is therefore unlikely that the case for or against state regulation of markets on grounds of 'market failure' or 'state failure' can be convincingly made from first principles or on an a priori basis (Kirkpatrick et al, 2004).

One of the most important shortcomings in the transition process is corruption. Many economists point to one major cause of corruption: bad regulation. Ill-designed policies create corruption incentives for policy makers, bureaucrats and the public in general. From this perspective, it is not the size of government that is the problem, but rather the details of programme and their administration. Reform should avoid rules that are complicated and difficult to administer and should design individual incentives to promote honest decision making. Thus, some 'good' regulation can help contain corruption. For example, privatisation in Eastern Europe involved bribery 
because there was too little 'good regulation'; that is, there were too few legal requirements that restricted corrupt deals. Detecting bad regulation and misdirected state intervention can be helpful in identifying areas in which corruption is likely to occur. Bad regulation and corruption are quite often two sides of the same coin. When domestic firms are given preferential treatment in public tenders, this may induce corruption, but it may also be the outright result of strong private interests that capture public funds. In such cases, corruption causes bad regulations, and not the other way round.

A final concern is that the difference between 'bad' and 'good' regulation is far from obvious. One criterion could be whether a regulation creates opportunities for corruption, but then the argument becomes circular and we have no causal theory of corruption. Overall, looking for 'bad' regulation provides some hints for detecting corruption, but falls short of an overarching approach to reform. Even regulations that have strong public justifications as responses to health, safety and environmental concerns can be subject to corrupt pressures (Liou, 2000).

\section{Concluding Remarks}

One of the several critical issues related to the successes and shortcomings in transition economies is privatisation, which is complex and difficult and itself only a prelude to restructuring.

Privatisation process includes denationalisation, regulation/deregulation and contracting out (lease, contract for concessions etc.). For most transition countries, the privatisation experience is a complex of these activities. However, because the restructuring was largely left to market forces, the emphasis was almost exclusively put on deregulation. This led to insufficient attention being paid to creating supportive regulations and institutional capacity ensuring that restructuring decisions were socially desirable.

The transition process has demonstrated the need for an effective and accountable state and the dangers of state desertion. It has also shown the importance in economic life of institutions, path dependence, banks, and financial fragility. It has made clear the need for effective economic policy to take account of structural and country-specific factors. And it has shown that privatisation is much more complex than many foreign advisers thought at the beginning of the transition process. In retrospect, they were rather ignorant about the methods, sequencing, and consequences of privatisation (Ellman, 2012). The transition economies have arrived at a number of different destinations. Because every country has different characteristics, social value and objectives, there is a need to work on each country transition as an individual experience.

Finally, it can be suggested that the role of the state in the transition economies is ambiguous. An important question raised is the size and relative strength of the state in transition economies. Specifically, when the state uses regulatory institutions, this question becomes more important.

\section{References}

- $\quad$ Aghion, P. and Schankerman, M. (1999), "Competition, entry and the social returns to infrastructure in transition economies”, Economics of Transition, 7 (1), p.80.

- Banerjee, S.D. and Munger, M.C. (2002). Move to Markets? An Empirical Analysis of Privatization in Developing Countries, p.1. http://www.feem.it/web/activ/_wp.html (20/03/2014).

- Bjornskov,C. and Potrafke,N. (2011), "Politics and privatization in Central and Eastern Europe A panel data analysis", Economics of Transition, Vol. 19(2), p. 201-2.

- Csaba, L. (2005), "Regulation and Public Sector Development: A Post-Transition Perspective”, PostCommunist Economics, Vol. 17, No. 2, p.148.

- Commander, S., Dutz, M. and Stern, N. (1999), "Restructuring in Transition Economies: Ownership, Competition and Regulation", the Annual World Bank Conference on Development Economics, Washington, D.C., April 28-30, p. 9, 28.

- Donnorummo, B. (2006), "The Political and Economic Complexities of Transition. Keynotes Address", Zagreb International Review of Economics and Business, Special Conference Issue, p. 14, 20, 2-3.

- Ellman, M. ( 2012), "What did the study of transition economies contribute to mainstream economics?", RRC(Russian Research Center) Working Paper Special Issue, No.2, p. 1,4, 6, 8, 17-8, $26,34$.

- Estrin, S. (2007), "The Impact of Privatization in Transition Economies", in the New Palgrave Dictionary of Economics, 2nd Edition, p. 2, 14, 17.

- $\quad$ Estrin, S. Hanousek, J., Kocenda, E. and Svejnar, J. (2009), The Effects of Privatisation and Ownership in Transition Economies, Journal of Economic Literature, vol.47, no.3, September, p.703

- Gregory, P. R. \& Stuart, R. C. (2001), Russian and Soviet Economic Performance and Structure, 7th Edition, Prentice Hall, p.261.B 
- $\quad$ Kirkpatrick, C., Parker, D. and Zhang, Y.F. (2004), Regulatory Impact Assessment in Developing and Transition Economies: A Survey of Current Practice, Centre on Regulation and Competition, Institute for Development Policy and Management, University of Manchester, p.3.

- Koyame-Marsh, R.O. (2011), “The Complexities of Economic Transition: Lessons from The Czech Republic and Slovakia", International Journal of Business and Social Science, Vol. 2, No. 19, [Special Issue - October], p.71.

- Liou, K. T. (2000), “Development Experiences in Economic-Transition Countries: Backround and Issues", International Journal of Economic Development, 2(1), p. 6.

- Miller, Jeffrey (2013), "Chapter 10 Privatization", in Handbook of the Economics and Political Economy of Transition, Paul Hare (ed.) and Gerard Turley (ed.), Routlegde International Handbooks, p.134, 136-7.

- Nishimura, Yoshiaki (2001), "Economic Policy for Transition to Market Economy-Overview”, Economic and Social Research Institute, p.1, 3, 4, 7. www.esri.go.jp/en/tie/russia/russia1-e.pdf (07/03/2014).

- Nuti, D. Mario (2013), “Chapter 3 Did We Go About Transiton in the Rigth Way?”, in Handbook of the Economics and Political Economy of Transition, Paul Hare (ed.) and Gerard Turley (ed.), p.53.

- Roland, G. (2000), Transition and Economics- Politics, Markets and Firms, MIT Press, Cambridge, p. 2301 .

- Scarlat, C. \& Scarlat, E. I. (2007), "Theoretical Aspects of the Economic Transition: The Case of Romania”, Managing Global Transitions, 5 (4), p. 316.

- Simoneti, M., Damijan, J. P., Rojec, M. and Majcen, B. (2004), “Case-by-case versus Mass Privatization in Transition Economies: Owner and Seller Effects on Performance of Firms in Slovenia”, LICOS Centre for Transition Economics LICOS Discussion Papers, Discussion Paper 143/2004, p. 8.

- Sonin, K. (2013), "Perspectives on Transition and Institutions The end of economic transition Lessons for future reformers and students of reform", Economics of Transition, Vol. 21(1), p. 4, 7. 